\title{
Transfer Pricing: A Multinational Strategy
}

\author{
Vernon E. Sweeney \\ Linda S. Sweeney \\ Sam Houston State University \\ Huntsville, Texas
}

\section{Introduction}

In large firms, diseconomies of scale cause long-run average costs to increase, and management becomes less efficient. The answer to the problem of lost efficiency has been the decentralization of the large firm. The firm is divided into product lines, or territorial, or multinational divisions, that are separate profit centers. Each profit center (foreign or domestic) is directed by a manager whose salary and bonus depend upon the performance of that division. The profits of each division will depend in part upon the interfirm or transfer price. A transfer price is the price that one subsidiary charges another subsidiary for goods and services exchanged between the divisions. An inappropriate transfer price may lead to maximized profits in one division, but result in decisions made by the other division which reduce the total profits of the firm. A transfer price may be assigned as a strategy that will optimize multiple objectives. These objectives are:

(1) Adapting to currency fluctuation.

(2) Reduction of import tariffs.

(3) Avoidance of exchange control.

(4) Reducing income tax liability.

A subsidiary operating in a country where exchange rates are appreciating relative to the US dollar may appear to be performing efficiently as revenues are translated into US dollars. However, examination reveals that rising revenues are not the result of good management and that performance bonuses are not indicated. Accounting statements adjusted by appropriate transfer prices yield realistic appraisal of the company's financial condition.

Low interfirm transfer prices between multinational affiliates allow the imposition of low ad valorem import tariffs. As long as the corporate income tax rate is low and the import duties are high, low transfer prices give the firm an advantage.

A country that exercises control over repatriation of profits will expect to encounter firms that use transfer prices between parent and local subsidiary which will reduce profit levels for the subsidiary to a minimum.

Recent announcements suggest that the Clinton Administration will tax foreign corporations doing business in the United States at higher tax rates. Tax rate differentials between countries may aggravate transfer pricing problems as multinational firms seek to avoid or minimize taxes. There is general agreement by scholars, reinforced by a series of new tax rules, that the most important abuse of transfer pricing is the use of 
transfer pricing to reduce corporate income taxation (Abdullah 1989; Arpan and Radebaugh 1985; Levey, et al. 1989).

To illustrate the transfer pricing problem, consider a French firm producing a product whose cost of production is $\$ 40$. The French firm sells the product to its Irish subsidiary at a price of $\$ 40$. The tax rate on corporate income in France is 48 percent, but since there was no profit in the transaction, there is no French tax liability. The Irish subsidiary sells the same unit to the American parent for $\$ 120$, earning an $\$ 80$ profit. Ireland's industrial development tax rate is but 4 percent, resulting in a tax obligation of $\$ 3.20$. In the United States, over the strenuous objection of the US manager and the IRS, the item is sold at $\$ 120$, earning no profit. If tax rate on business profit in the United States is 34 percent, the transaction in the US made no profit, and therefore the firm has no tax obligation on the transaction.

This multinational strategy allows the Irish subsidiary to loan capital funds to both the French and American firms at low interest rates as compensation. Transfer prices of the type described above not only evade legitimate taxes, but misallocate resources.

\section{Transfer Pricing Methods}

Controlling the abuse of tax rate differentials with interfirm transfer prices, as in the example above, has become an important concern of tax authorities around the world. Arpan and Radebaugh found that reduction of tax obligation was the major factor in interfirm pricing decisions by multinational corporations (Arpan and Radebaugh 1985).

In the early part of this century, most firms made one product or a narrow line of related products. Then distribution firms began to integrate backward into manufacturing, and manufacturing firms integrated forward into distribution. Vertical integration of firms was followed by the development of interfirm transfer pricing. One issue in the Department of Justice case against AT\&T, Western Electric, and the Bell Telephone system in the 1960s was the alleged abuse of interfirm pricing to the Bell system, giving that firm an advantage over independent telephone companies.

Allocation of resources within the market is the role of prices in economic theory. Inappropriate transfer prices misallocate resources within the firm. Jack Hirshleifer wrote an early paper on transfer pricing, approaching it as a problem in marginal analysis.

Hirshleifer said that the price is determined by the market only when the transferred or intermediate good was exchanged in a perfectly competitive market. In other cases, the optimal solution was marginal cost or a price between marginal cost and market price. According to Hirshleifer, the marginal cost solution applies only if two conditions hold. The first is the assumption of technological independence, which means that the operating costs of the divisions are independent of each other. The second condition, of demand independence, states that an external sale by either division does not affect the demand of the other division. He concluded that transfer prices applied only to short-term decisions with no change in existing capacity (Hirshleifer 1956). 
There are difficulties with practical application of the economic approach to transfer pricing. First, very few transferred goods are exchanged in perfectly competitive markets. Second, marginal cost is often hard to calculate from information gathered by cost accounting systems, and marginal cost pricing focuses on economic decisions and is not concerned with the policies for performance measurement, evaluation, reward, and individual fairness (Eccles 1985).

\section{Accounting Theory}

The objective of accountants, like economists, is to arrive at a transfer price that will result in decisions made at the divisional level that will optimize the firm as a whole. Transfer pricing will affect output levels of all related divisions, the amount of the product the selling division will transfer, the amount the buying division will source internally, make-order decisions, capital budgeting, and pricing of the final goods. Therefore, accountants debate whether market price or standard variable cost should be used. In some situations, standard variable cost approximates marginal cost (Eccles 1985).

The current accounting view on the transfer pricing problem is expressed by Anthony and Deardon. They believe market prices should be used if they are available. This makes the selling division look at make-or-buy decisions and produce only products that will earn a sufficient profit. Cost-based prices should be used when market prices or rough estimates are not available. Anthony and Deardon make the point that full cost transfers can cause the division selling the final good to produce at a level that optimizes its profits, but full cost price may be too low to optimize corporate profits. As in the economic approach, the accounting approach has no role for strategy and administrative process of transfer pricing policies. Also, the criterion for individual fairness is not addressed in accounting theory (Eccles 1985).

\section{Management Theory}

Management theory, regarding interfirm pricing, deals with the relationship between transfer pricing practices and administrative processes. It presents a broader view on the problems of management than economic or accounting theory. Managers generally replace the profit maximizer with profit "satisficer", where rewards are not connected as strictly to divisional performance. Bonuses and salary increases may be influenced by subjective qualitative standards and corporate performance.

Transfer pricing is a way of communicating corporate strategy. The rules of transfer pricing can be negotiated to improve the measured performance of a unit. Transfer prices are part of a bargaining process in which division managers try to solve divisional problems. Fairness and management of conflict, along with economic decision making, are as important as divisional profitability, and in the long view, may be instrumental in reaching optimum firm profitability (Eccles 1985). 


\section{Cases Illustrating Transfer Pricing Issues}

Diversified multinationals are concerned with the selection of transfer prices in order to avoid retribution by governments of the world (Arpan and Radebaugh 1985). The Tax Reform Act of 1986 (TRA) brought renewed interest to the transfer pricing issue because corporate tax rates were reduced, and the United States became a tax haven for some multinational corporations. The TRA instructed the Internal Revenue Service to study and interpret the intercompany pricing rules in Code Section 482.

Section 482 puts intercompany sales on par with sales involving unrelated parties, or "at arm's length." The Treasury regulations which interpret this section provide the following methods to arrive at arm's length prices:

(1) Comparable uncontrolled price - This price is determined by comparing sales in which buyers and sellers are not related through corporate affiliation.

(2) Resale price - This price is determined by comparing controlled and uncontrolled resales of products to establish an acceptable gross profit percentage.

(3) Cost-plus percentage - This is determined by comparing the markup on the cost of goods sold in uncontrolled sales.

These three methods for pricing tangible property, called the pricing comparability standard, must be successfully applied to achieve an "arms length" price. An additional fourth method has sometimes been used:

(4) The profit split - A "reasonable" distribution of income between two or more contributing divisions within the firm.

The pricing of intangible property is also addressed in Section 482. Any income from an exchange or license of intangibles must be "commensurate with the income attributable to the intangibles" (Levey, et al. 1989).

Guenter Schindler found that more than two-thirds of the corporations surveyed stated that the arm's length standard was difficult to apply. In some vertically integrated industries, there are few transactions involving unrelated parties. The transfer of valuable intangibles is not easily priced using the comparability standard. A company does not often sell valuable intangibles to its subsidiaries or to unrelated parties (Schindler 1988).

The IRS has ample authority in determining the amount of income allocation as a result of intercompany pricing. In an audit, the transfer pricing rationale can be overturned. These disagreements can lead to appeal and litigation which can last for years. For this reason, a majority of the transfer pricing issues are settled out of court between the corporate tax department and revenue agents (Schindler 1988).

Because of the deficiencies above, the IRS proposed Revenue Procedure 91-22, generally called an "advanced pricing agreement," (APA). Revenue Procedure 91-22 required a taxpayer to propose a transfer pricing methodology and to submit documentation (which can be extensive) to show that the taxpayer had set an "arm's length" 
transfer price, all this before the actual transaction. When the IRS completes its analysis of the taxpayer's documents, the participants may enter into an APA (Paul 1991).

On January 13, 1993, the IRS published 146 pages of rules to clarify and replace the unworkable "arms length" standard. Alan Wilensky, acting assistant Treasury secretary for tax policy, summarized these rules as requiring the taxpayer to use an interfirm price policy which is based on the actual functions performed by the corporate unit selling the product or service (Wartzman 1993).

\section{The Eli Lilly Case}

The case of Eli Lilly and Company v United States is an example of the difficulties involved in complying with the rules of Section 482 . Eli Lilly ("Lilly") purchased the drug Darvon from its wholly owned manufacturing subsidiary in Puerto Rico, Lilly P.R. They entered into a pricing agreement whereby Lilly P.R. was given the manufacturing rights, and Lilly would market the product worldwide making use of its name, reputation, and sales force (the marketing intangibles) (Rafferty 1989).

Lilly was audited in 1969 and agreed to adjustments to its transfer price for Darvon. In spite of these adjustments, the IRS determined a deficiency for years 19711973. According to the IRS, Lilly P.R.'s prices for Darvon sold to Lilly were not in accordance with the arm's length standard. About $\$ 75$ million in income was reallocated to Lilly in the United States, subject to a 34 percent tax rate (Rafferty 1989).

\section{The Bausch and Lomb Case}

Bausch and Lomb Corporation (B\&L) decided to expand its soft contact lens manufacturing capabilities in the 1970s. A new manufacturing facility was established in the Republic of Ireland. A major consideration in this decision was an income tax exemption by the Republic of Ireland on all export profits through 1990. B\&L entered into a licensing agreement with $B \& L$ Ireland for the right to use certain manufacturing intangibles and the $B \& L$ trademarks. In exchange, the affiliate agreed to pay $B \& L$ a royalty of five percent of net contact lens sales. This was common to the contact lens industry (Shanda 1989).

The IRS reallocated income for the years 1979-1981 in order to state its opinion of the arm's length consideration for the intangibles licensed to B\&L Ireland. As a result of the notice of deficiency, the case went to the Tax Court in Bausch and Lomb Inc. 92 TC No 33. The Court ruled that a five percent royalty for the use of licensed intangibles was not appropriate and determined a twenty percent royalty based on a 50-50 profit split. The IRS reallocated income from B\&L Ireland to B\&L stating that $\$ 7.50$ was not an arm's length price because B\&L could manufacture the product for $\$ 1.50$. The IRS said that a seller could not purchase a product for $\$ 7.50$ that it could produce for $\$ 1.50$ (Farber and Silverman 1989).

The Court ruled against the IRS' arguments. It found that Bausch and Lomb was a distributor of contact lens purchased from its subsidiary, and that comparable sales from manufacturers to distributors should be used. The transfer price of $\$ 7.50$ was an 
arm's length price, and that by reallocating the income, the IRS had abused its discretion (Farber and Silverman 1989).

In addition to the two landmark cases outlined above, the IRS has successfully prosecuted transfer several recent cases that involve the Japanese firms, Toyota and Yamaha, and the U. S. firms, Westinghouse and Apple Computer. According to the Wall Street Journal, the services of an arbitrator will be used in an attempt to settle the Apple Computer case. The use of arbitration, if succesful, may represent a new approach to the transfer pricing problem (Wall Street Journal April 3, 1992).

\section{Conclusion and Recommendations}

Managers of decentralized firms, using transfer pricing as part of a strategy to reach their firms' goals, must review and document their transfer pricing procedure with more care than most have devoted to the task in the recent past. The IRS will probably rely on the "advanced pricing agreement" to identify those transactions that require special attention, and the rules of January 13, 1993, to determine the legitimacy of the transfer price (Wall Street Journal April 3, 1992). An article in the Wall Street Journal, on January 20,1993, said that the Treasury was calling for a new study of the multinational portions of the tax code, and that the current code in that area was "excessively complex" (Wartzman 1993). Interpretation of the newly issued transfer pricing regulations (January 13, 1993) seem to provide for greater flexibility than earlier proposals however, there are increased documentation requirements.

A detailed strategy for United States multinational corporations will be different for each corporation because of differences in subsidiary location, type of product(s), and unique market structure features. However, a basic strategy in the opinion of the authors will include:

(1) Compliance with record and reporting stipulations contained in Section 6038A of the Internal Revenue Code.

(2) Detailed documentation to provide evidence of arm's length pricing between the firm's subsidiary units.

(3) Using the data from items 1 and 2 above, negotiate the most favorable Advanced Pricing Agreement possible with the Internal Revenue Service.

A massive federal deficit and the lack of new revenue sources have focused the interest of the IRS multinational taxation, but IRS policy remains fluid and less than predictable. Legislation in this technical area is adequate, but the law continues to be shaped by the "white papers" of policy makers in the IRS, and ultimately tempered by the dicta and the rules of law that originate from the various levels of the judiciary. 


\section{References}

Abdullah, W. M. 1989. "How to Motivate and Evaluate Managers With International Transfer Pricing Systems." Management International Review 29 (Winter): 65-71.

Arpan, J. S. and L. H. Radebaugh. 1985. International Accounting and Multinational Enterprises. New York: Wiley: 261-263.

Badaracco, Joseph L., Jr. 1991. The Knowledge Link: How Firms Compete Through Strategic Alliances. Boston: Harvard Business School Press.

Eccles, Robert G. 1985. The Transfer Pricing Problem. Lexington, Mass.: D. C. Heath: 21-24.

Farber, Peter L. and Mark J. Silverman, Editors. 1989. "Discretion Abused in Reallocating Income." Journal of Taxation 70 (June): 330-332..

Hirshleifer, Jack. 1956. "On the Economics of Transfer Pricing." Journal of Business 29: 172184.

Hoshower, Leon B. and Linda Ann Mandel. 1986. "Transfer Pricing Policies of Diversified U. S. Based Multinationals."International Journal of Accounting_22 (Fall): 51-59.

Levey, Marc M., Stanley C. Ruchelman, and William R. Seto. 1989. "Transfer Pricing of Intangibles After the Section 482 White Paper."Journal of Taxation 71 (July): 38-46.

Liao, Woody M. and James L. Boockholdt. 1988. Cost Accounting for Managerial Planning, Decision Making, and Control. Houston: Dame Publications.

Paul, Herbert. 1991. "IRS Agreement on Transfer Pricing Now Possible."Journal of Accountancy 9 (July): 23-25.

Rafferty, James G. 1989. "The Profit Split Method of Income Allocation in Intercompany Pricing Disputes: The Eli Lilly Case." Taxes 64 (October): 662-671.

Schindler, Guenter. 1988. "Intercorporate Transfer Pricing." The Tax Advisor 19 (May): 378384.

Shanda, Lawrence P. 1989. "Royalties and Super-Royalties."Taxes 67 (September): 576-582.

Staff Reporter. The Wall Street Journal, April 3, 1992, p. A12.

Wartzman, Rick. The Wall Street Journal, January 14, 1993, pp. A3-A4.

Wartzman, Rick. The Wall Street Journal, January 20, 1993, p. A6. 